\title{
Site investigation of open dumping site of Municipal Solid Waste in Faisalabad
}

\section{Hafsa Yasin ${ }^{1 *}$ and Muhammad Usman ${ }^{1}$}

${ }^{1}$ Department of Structures and Environmental Engineering, University of Agriculture Faisalabad, Pakistan *Corresponding author's e-mail: hafsayasin6@gmail.com

This is an open access article distributed under the Creative Commons Attribution License, which permits unrestricted use, distribution, and reproduction in any medium, provided the original work is properly cited

\section{ARTICLE DETAILS}

Article history:

\section{Received 26 October 2016}

Accepted 10 December 2016

Available online 9 January 2017

Keywords:

MSW, open dumping site, environmental concerns

\section{ABSTRACT}

Inappropriately solid waste handling and disposing are promoting environmental problems in Pakistan. Deteriorating environmental quality is a serious consequence of open dumping site and is rapidly increasing concern for public. To investigate, the causes Muhammada Wala dumping site was chosen. There is a tremendous amount of solid waste generating and dumped without any precautionary measures. Due to development of industries and urban areas the condition is going to be harsh. The aim of this study is the site investigation of the dumping site and its consequences on environment. Water samples were collected near the site, analyzed in the laboratory and interviews were taken. Significant high TDS was observed in ground water. Communicable diseases and unhygienic environment were revealed from this research. The main collapses of municipal solid waste systems are unplanned management of the city, intense climatic conditions, absence of awareness of users and community participation, inadequate resources including machinery and lack of funds.

\section{Introduction}

The intimidation of environmental deterioration has been evocating the people around the globe since early times and is still raising because of uncontrolled growth in countries that in developing stage. [1]. Solid waste means any garbage, refuse, sludge or any material that is thrown away as unwanted rom any activity of humans while the municipal solid waste also known as domestic waste is a variety of waste consisting of routine items that are thrown away by public [2].

Global municipal solid waste production levels are approximately 1.3 billion tons per year which is almost the twice as compared to recent decade. With the passage of time it will go towards the increasing trend. This increase in waste is associated with populations, rapid urbanization and economic development. As income-level and urbanization increases, the consumption of good and services co-relatedly increases, as does the amount of waste generated. Urban residents generate about twice as much waste as their rural habitants [3].

Pakistan generates 20.024 Million tons a year which is about 59,000 tons/day. Waste generation tempo alters from $0.23 \mathrm{~kg} / \mathrm{c} /$ day to $0.61 \mathrm{~kg} /$ $\mathrm{c} /$ day in rural and urban areas correspondingly [4]. The worldwide average is $1.2 \mathrm{~kg} / \mathrm{c} /$ day [5]. The waste generation rate of Faisalabad is $0.48 \mathrm{~kg} / \mathrm{c} /$ day [6]. Faisalabad formally called Lyallpur which is in the 3rd rank city in Pakistan and $2^{\text {nd rank }}$ city in the province Punjab. It is famous for its high quality of textile items [7]. The citizenry of Faisalabad is more than 4 million and daily generation of waste is about $1350-1500$ tons but the carrying capacity is only 900 tons, out of which only 600-700 tons are disposed in open dumping site. The remaining waste remains in open areas like empty plots or unconstructed areas and sometimes remains on road side in a form of litter. The average solid waste generation rate in Faisalabad is $0.5 / \mathrm{c} /$ day [8].

In developing countries, open dumping is typical method for waste disposal due to low allowances and absence of skill expertise. An open dumping is defined as a land discarding location at which solid wastes are thrown away in a way that does not safeguard or shield the territory or domain, are receptive to open burning, and are revealed to the nearby community vectors, and scroungers .Open dumping is an ordinary method adopted for waste disposal. It causes serious risk and damages to the environmental factors. Soil fertility is being affected by contaminants present in waste. Crop production is directly linked with soil properties. So, open dumping is indirectly affecting the crop production .Secondly uncontrolled release of obnoxious odors are playing their contribution to greenhouse gases. Production of leachate deteriorates the quality of ground water and soil. Due to hazardous impacts of commingled waste they are hitting the human health of people near the dumping site. The aim of this study is to investigate the environmental impact due to the current exercise of disposing of municipal solid waste in respective of human health, crops, and water and waste pickers at the site Muhammada Wala at Jaranwala road so as to provide baseline data on problems to decision makers that help in making remedial action.

\section{Description of the Study Area}

The dumping site is situated at Muhammada Wala near Central Jail, Jaranwala road .Geographically it is situated at $31^{0} 23^{\prime} 8$ "'nothern latitude and $73^{\circ} 14^{\prime} 26^{\prime \prime}$ eastern longitude at $182.93 \mathrm{~m}$ above sea level (Fig 2.1). Climatologically the Faisalabad lies in the semi-arid zone with long and hot summers and cool dry winters. The highest temperature of the region goes $48^{\circ} \mathrm{C}$ in the summer last year. The summer season initiates from Mid-April and goes up to late-October. In June the climate remains hot and dry as it is the hottest month of the year in this region, while July, humidity is found mostly in July, August and the first half of September, with exception of the days when there is rainfall. While the January is the coldest month, with dry cold and foggy days. The Pakistan Department of Meteorology depicts an annual average rainfall of $375 \mathrm{~mm}$ [9].

The dumping site covers an area of about 75 acre approximately, which is filled with pile of solid waste on open area. Actually it was the barren land or coloured land and was used for dumping of waste firstly in 1990.The area was below the surrounding area. It was filled with waste with passage of time. When that below area became equal to surrounding land it was levelled with bulldozer. Now the second layer of waste is going on the land. There are 400 FWMC vehicles which carry only municipal waste to disposal site. Each vehicle is subjected to 3 turns in a day which means total 1200 times waste is carried to side. 
Daily generation of MSW is $1300-1600$ tons/day, but 900 tons is the carrying ability of solid waste by a number of vehicles that are available to city Government. The rest of solid waste remains in the open regions of different vicinity like empty un-built patches in the suburban and commercial areas.The administration disposes of only 600 to 700 tones. The remaining waste is left to litter streets and roads causing health and environmental diseases [7].

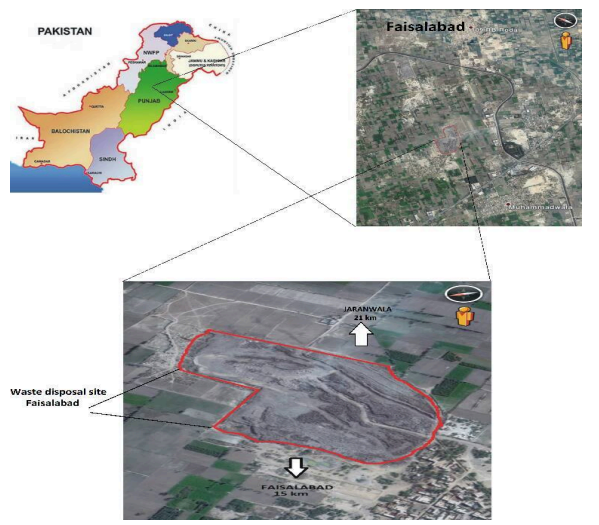

Fig 1: Open dumping Site near Muhammada Wala

\section{Methodology}

\subsection{Field Surveys and Interviews}

Field survey for the research were carried on 10.02.2017, 11.02.2017, 16.02.2017, and 17.02.2016. The different samples of water were collected and regulated according to the guidelines. Field visits also included interviews with waste-pickers, drivers of FWMC vehicles, nearby residents and small scale farmers related to their health, animals, crop and water drainage etc.

\subsection{Analysis of water samples}

The three points for water sample were selected. They all were located near the dumping site at various distances. The sample A was taken from the pump which was very near to dumping site almost at a distance of 500 meter. The sample B was taken from the back side of dumping at the distance of 600 meter. The sample $C$ was taken from the nearby village where there were people along with animal lived. The water samples were prepared for transportation in special boxes and then taken Laboratory for analysis.

\section{Site Investigation and Results}

\subsection{Types of waste at the dumping site}

This site is specific for municipal waste of 4 towns of Faisalabad. That include Madina town, Lyallpur town, Jinnah Town and Iqbal town [7].

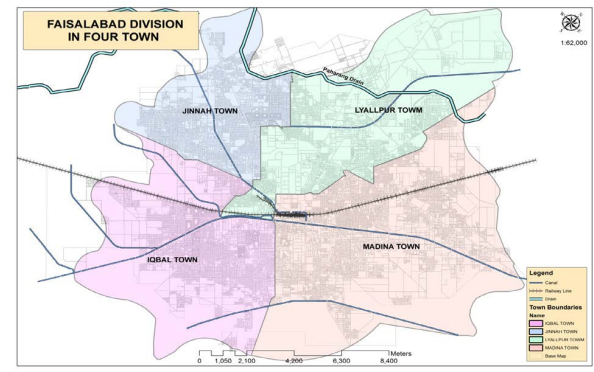

Fig 2: Collection Areas of Waste in Faisalabad

It includes the following waste

Garbage (food waste, kitchen waste, Green waste etc.)

Rubbish (paper, wood, newspaper etc.)

Textiles waste

Broken plastic and glass items

A large quantity of plastic rapper

Nappies

Steel items

Metal items

Electronic waste

Packaging waste (tetra pack, boxes, containers etc.)

Rubber waste

Broken Furniture [7]

\subsection{Waste Composition}

Physical composition explains the individual elements of solid waste heaps and their relative proportion usually based on \% by weight. Average values of different components are listed below

Table 1: Physical Composition of MSW

\begin{tabular}{|c|l|c|}
\hline Sr. No. & \multicolumn{1}{|c|}{ Waste Component } & \%/weight \\
\hline 1 & Plastic \& Rubber & 6.60 \\
\hline 2 & Metals & 1.00 \\
\hline 3 & Paper \& Cardboard & 7.67 \\
\hline 4 & Rags/ Textile waste & 6.53 \\
\hline 5 & Glass ceramics & 2.43 \\
\hline 6 & Bones & 2.40 \\
\hline 7 & Food Waste & 33.81 \\
\hline 8 & Leaf, Grass \& Straw & 7.36 \\
\hline 9 & Wood & 1.07 \\
\hline 10 & Animal Waste & 2.34 \\
\hline 11 & Dust, Dirt, Ash, Bricks, stone & 28.79 \\
\hline \multicolumn{2}{|c|}{ Total } & $\mathbf{1 0 0 . 0 0}$ \\
\hline \multicolumn{2}{|c|}{ (Source: FWMC, 2015) } \\
\hline
\end{tabular}

\subsection{Waste Handling Practices at the Site}

Almost 15-20 waste pickers can be seen on the site on any particular day. Usually, they come for exploring the plastics like coke bottles, tires and metal items such as aluminum cans etc. After separating they bound in a form of bales. What they find they will sale at modest price and get almost Rs 300 to 400 . On daily basis. Some waste-collectors are native and go to the dump site daily. Some waste-pickers that interviewed described that they come from Dudianwala to dumping site from $6 \mathrm{am}$ to $3 \mathrm{pm}$. During the time of segregating the waste-pickers use utterly no personal protection equipment (masks, gloves etc.), when they pick recyclable or useful materials. As the FWMC vehicles arrive, the pickers immediately stand near the vehicles so that to obtain a good opportunity of picking or collecting anything useful. It is very obvious from visiting the site that there are a wide variety of severe health risks that are encountered by the pickers. Waste-pickers that interviewed set the examples of those hazards and risks that they have to face daily. The burning of waste is a routine event so that it lessen the size of piles. The noxious emissions of gases produced by the application of combusting solid waste that also includes hazardous substances is a serious ultimatum to the health of the waste-pickers.
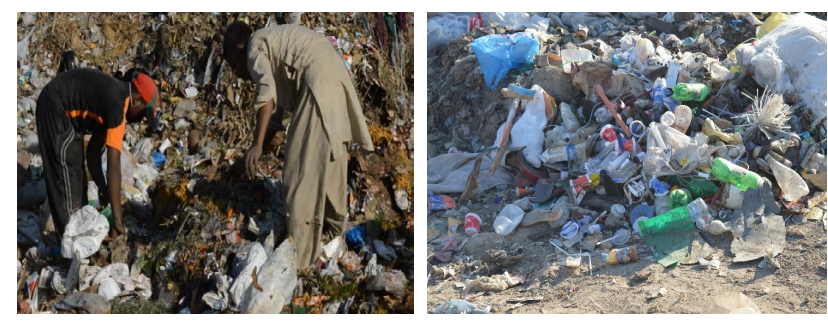

Fig 3: Activities at the Site

\section{Significant Environmental Concerns}

An extensive and frame evaluations of the environmental concerns was hampered by the shortage of information and official data but the explanation of the significant and important issues should be seen by conducting a preliminary exploration and examination only.

\subsection{Carrying of Waste by FWMC Vehicle}

The poor management of waste dumping site arises many problem. Firstly the FWMC vehicles take no precautionary measure at all to take waste from stations to disposal site. They just load the waste on the vehicle in unmannered way. Even the net used for covering the waste is teared from many side and this teared net is again partially cover the waste. The vehicle is distributing waste on the road side from initial position to the end point that is disposal point. This poor management disturbs the traffic as well as environmental factors.
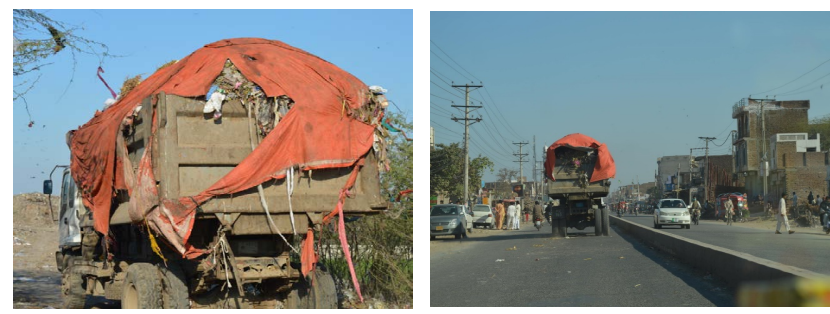

Fig 4: Unmannerly Carrying of Waste 
5.2 Effects on Human Health.

Open dumping spreads bad odors.

- $\quad$ As burning of waste creates smoke that disturb the human health in many ways.

Vermin, Microbes and viruses have ideal place for growth so it becomes the origin of many diseases.

Dumpsites provide an ideal conditions for mosquitoes to grow and expand its amount. It can increase 100 times more rapidly as compared to normal conditions. Many serious health

illnesses, include dengue fever, have been ascribed by ailmentconveying mosquitoes.

It pollutes the land of surrounding areas.

The polluted air causes a problem of respiration and headache by moving from one side to other.

Cough is reported as most common problem which remain throughout the year.

People mostly affect by allergy.

\subsection{Effects on Crop}

- The vegetation level of sites manifests that in spite of basic constitution, multiplicity is suffering due to open dumping of wastes.

The near crops show less greenery

They are of small height as compared to normal crops

They give less production.

Most importantly, water passage to crops is blocked by waste spreading here and there. When air blows fastly, it carries waste from heaps of waste to water channels.

\section{Results Analysis and Impact Evaluation}

The results of water samples are listed below

\section{Table 2: Different Parameters of Ground Water}

\begin{tabular}{|l|l|l|l|}
\hline Parameters & Water sample A & Water Sample B & Water Sample C \\
\hline pH & 8.13 & 8.0 & 7.8 \\
\hline TDS $(\mathrm{ppm})$ & 2000 & 1890 & 1668 \\
\hline EC $(\mathrm{S} / \mathrm{m})$ & 0.40 with $24.6^{0} \mathrm{C}$ & 0.40 with $25^{\circ} \mathrm{C}$ & 0.49 with $24.6^{0} \mathrm{C}$ \\
\hline Turbidity(mg/L) & 128 & 110 & 98 \\
\hline
\end{tabular}

The results shows high level of TDS which is directly showing ground water contamination

\section{Conclusions}

All major cities of Pakistan show deficiency in waste disposal practices and lack of any properly and managed facility for waste disposal. At present waste is dumped openly on land or any free space or depressions. Like all cities of Pakistan, Faisalabad does not have any integrated strategy for solid waste management. Municipal solid waste is being thrown in the corners of streets, some unconstructed areas and in the backward areas and sometimes partially burnt which results in unclean environment, outburst of diseases and environmental pollution. Waste collection system is quite scant as it collects only 600-700 tons/day out of 1300-1600 tons/day. The FWMC vehicles are not adequately covered with net. In nutshell, waste is disposed of in un-engineered methods as there are no pragmatic techniques and mechanisms that are present at the dumping site for secure disposal or treatment which ultimately deteriorates the environmental factors of life.

\section{Recommendations}

- $\quad$ There should be properly covered vehicles with net that are carrying waste.

The workers should be given a proper training related to their work.

Residents near the side should be given awareness about the safety precautions.
There will be regular checking system of water channels blockage by waste in order to irrigate nearby crops.

The enforcement of laws should be strong and penalty will be given to workers if they neglect their duties.

- It needs to convert the site from open dumping to control dumping.

- $\quad$ There should the enclosure boundary (fence) around the Dump Site Area

- $\quad$ The waste that liter outside the dumping site or boundary during transporting should be readily removed.

- $\quad$ Application of cover material on daily (periodical) basis

- Inspection of incoming waste (only municipal solid waste).

- Waste should be compacted in order to make space for incoming waste

- $\quad$ There should be some sort of better separation of different material for further processing like composting.

\section{References:}

[1] Ali, S.M., Pervaiz, A., Afzal, B., Hamid, N. and Yasmin, A. 2014 Open dumping of municipal solid waste and its hazardous impacts on soil and vegetation diversity at waste dumping sites of Islamabad city. Journal of King Saud University, 26; 56-65.

[2] Ayyub, S. and Siddiqui, S. 2015. Municipal solid waste dumping practice and its Impact assessment. European International Journal of Science and Technology, 4 (3); 33-53.

[3] Lim, S., Lee, L. and Wu, T. 2016. Sustainability of using composting and vermicomposting technologies for organic solid waste biotransformation: recent overview, greenhouse gases emissions and economic analysis. Journal of Cleaner Production, 111; 262-278.

[4] MOE. 2016 Brief on Solid Waste Management http://www.pres.org.pk/?s=solid+waste+generation+in+pakistan (last accessed on 20-05-2017).

[5] World Bank Report.2012. What a waste: a global review of solid waste management http://siteresources.worldbank.org/ INTURBANDEVELOPMENT/Resources/336387-1334852610766/

Chap3.pdf (last accessed on 22-05-17)

[6] MOP. 2011. Terms and conditions for auction of solid waste of city of Faisalabad http://ipdf.gov.pk/prod_img/Terms\%20And\% 20Conditions\%20For\%20Auction\%200f\%20Solid\%20Waste.pdf (last accessed on 31-05-17)

[7] https://en.wikipedia.org/wiki/Faisalabad (last accessed on 18-05-17)

[8] FWMC. 2015. Action Plan to Expand Solid Waste Management Services to the Entire City Area. Faisalabad Waste Management Company.

[9] Wiki. 2017. Wikipedia Faisalabad. https://en.wikipedia.org/ wiki/Faisalabad\#Geology. (Last accessed on 20-05-2017) 